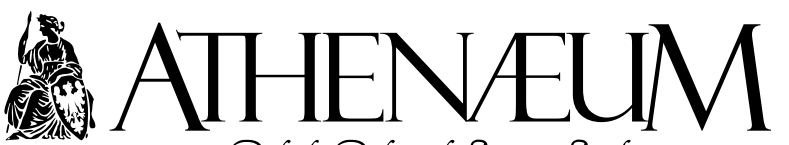

Polish Political Science Studies

Polskie Studia Politologiczne

vol. 72(4)/2021, pp. 106-118

DOI: 10.15804/athena.2021.72.06

www.athenaeum.umk.pl

ISSN 1505-2192

(c) $(1) \odot$

\title{
THE POLICY OF THE PARLIAMENTARY OPPOSITION IN NEGOTIATIONS WITH THE GOVERNMENT DURING THE EUROMAIDAN IN UKRAINE
}

\author{
STANOWISKO OPOZYCJI PARLAMENTARNEJ \\ W NEGOCJACJACH Z WŁADZAC PODCZAS EUROMAJDANU \\ NA UKRAINIE
}

Liana Hurska-Kowalczyk*৫

\begin{abstract}
- ABSTRACT
The objective of this article is to establish the main goal the leaders of the parliamentary opposition wanted to achieve in the negotiations with the government during the Euromaidan. In this study, the following methods were applied: the historical method, data analysis, and case study. In the conclusion, it is noted that the main task of the parliamentary opposition in the negotiations with the government was to restore the Constitution of 2004, which limited the presidential competences in executive power and extended the parliamentary competences in this respect.
\end{abstract}

Keywords: Ukraine; parliamentary opposition; Euromaidan; negotiations; protest
Celem artykułu było ustalenie głównego zadania, jakie zamierzali zrealizować liderzy opozycji parlamentarnej uczestniczący w negocjacjach $\mathrm{z}$ władzą podczas Euromajdanu. Podczas przeprowadzenia badania zostały zastosowane następujące metody: historyczna, analiza danych zastanych, case study. W podsumowaniu udało się ustalić, że głównym zadaniem, które stawiała przed sobą opozycja parlamentarna w negocjacjach $\mathrm{z}$ władzą, było przywrócenie redakcji Konstytucji z 2004 r., która ograniczała kompetencje prezydenta wobec władzy wykonawczej i zwiększała w tym zakresie uprawnienia parlamentu.

Słowa kluczowe: Ukraina; opozycja parlamentarna; Euromajdan; negocjacje; protest

* University of Szczecin, Institute of Political Science and Security Studies. 


\section{INTRODUCTION}

In November 2013, for the third time in the history of modern Ukraine, the Independence Square in Kiev became the centre of wide anti-government protests. In Autumn 1990, a student protest campaign took place there against the politics of the last Soviet government (at the time, still in the Ukrainian Soviet Socialist Republic), which has been remembered in history as the "Revolution on Granite" (a key element of the protest was the students' hunger strike on the granite pavement of the square). Next, in November and December 2004, the protests in the same place were a reaction against presidential election fraud (the "Orange Revolution" - as orange was the campaign colour of Viktor Yushchenko). The "Orange Revolution" was organised by the political opposition and its goal was to repeat the presidential elections. It had a single leader - Viktor Yushchenko, the opposition's presidential candidate. Every day, the protesters chanted "Yushchenko! Yushchenko!". The politicians controlled the protesters and steered the protests. Yet, the unfulfilled promises of the government made of the leaders of the "Orange Revolution" led to a disillusionment of citizens with politics (Wilson, 2014, p. 66). The Euromaidan (Maidan)' began on November 21,2013 as an initiative of social activists, journalists and non-governmental organisations, in reaction to the government's decision to suspend the process of signing the association agreement between Ukraine and the European Union (EU). As a result of the government's attempt to disperse a tent city on the Independence Square on November 30,2013, which was accompanied by assaults on the student demonstrators by the special police unit "Berkut", the Euromaidan transformed into wide anti-government protests that lasted till February 2014. Parliamentary opposition (All-Ukrainian Union "Fatherland" ["Batkivshchyna"], Vitaly Klitschko's Ukrainian Democratic Alliance for Reform [UDAR] and AllUkrainian Union "Freedom" ["Svoboda”]) joined the Euromaidan movement and attempted to gain control over it. In the end, the leaders of the parliamentary opposition (Arseniy Yatsenyuk - "Batkivshchyna”, Vitaly Klitschko - UDAR, and Oleh Tyahnybok - "Svoboda") became the representatives of the Euromaidan in the negotiations with the government.

1 The Independence Square in Kiev was the centre of the protests. In everyday language, 'maidan' is synonymous with 'square', therefore 'Independence maidan' signifies the place of protest. The protests have been named 'Maidan' or 'Euromaidan' (due to the direct cause of its initiation). The terms 'maidan' and 'Euromaidan' have been also used to stand for the community of protesters. 
The objective of this study is to establish the main goal of the leaders of the parliamentary opposition participating in the negotiations with the government during the Euromaidan. In this article, the following hypothesis is being verified: the leaders of the opposition used the Euromaidan as a means to limit the presidential power of Viktor Yanukovych. When Euromaidan started, the parties of the opposition were engaged in preparing themselves for the presidential elections which were to take place in 2015. As Viktor Yanukovych used force against the Euromaidan, and refused to accept far-reaching concessions in talks with the protesters, the opposition was convinced that it was not realistic to expect snap election. Therefore, in their media appearances, the leaders of the opposition stressed that the Euromaidan should last until the presidential campaign in 2015 and function as mobilisation, as well as limit the chances of electoral fraud (Panchyshyn, 2014). It can be therefore assumed that in a shortterm perspective, the opposition aimed at limiting the competences of the head of the state. To fulfil the research objective and to verify the hypothesis, the following methods are used: the historical method, data analysis, and case study. This research problematics has been discussed in the following academic studies: Aslund (2015), Hale (2015), Wilson (2014), Matsiyevsky (2016), and others.

\section{THE DEMANDS OF THE PROTESTERS}

During Euromaidan, the Ilk Kucheriv Democratic Initiative Foundation ("Democratic Initiative") and Kiev International Institute of Sociology (KIIS) conducted three polls among the protesters: 1) on December 7-8, 2013 (Maidanmeeting), 2) on December 20, 2013 (Maidan-camp), and 3) on February 3, 2014 (Maidan-Sich) ${ }^{2}$.

The results of these polls indicate that changes in the demands of the protesters occurred between December 2013 and February 2014 (see Table 1).

It may be concluded that in the last month of the protest, the issue of signing the association agreement between Ukraine and the EU was put on the back burner. Instead, the postulate of dismissing Viktor Yanukovych from the presidential office and calling snap presidential elections became the primary

2 Experts researching this topic have noted that the Euromaidan started as a peaceful protest (Maidan-meeting), then transformed into a Maidan-camp (tent city, the demonstrators living in the streets in the centre of the capital), and finally, after the so-called Dictatorship laws were introduced by the government on January 16, 2014, it took the shape of the Cossack Military Sich (brutal confrontations between force units and protesters), becoming Maidan-Sich (Bekeshkina, 2014, p. 306). 
Table 1. Protesters' Support for the Demands Made in the Euromaidan

\begin{tabular}{|c|c|c|c|}
\hline Demands of the protest & $\begin{array}{l}\text { Maidan- } \\
\text { meeting (\%) }\end{array}$ & $\begin{array}{l}\text { Maidan-camp } \\
(\%)\end{array}$ & $\begin{array}{c}\text { Maidan-Sich } \\
(\%)\end{array}$ \\
\hline $\begin{array}{l}\text { To free the arrested protesters of Maidan and } \\
\text { stop repressions against them }\end{array}$ & 81,8 & 63,9 & 82,2 \\
\hline To sign the association agreement with the EU & 71 & 58,6 & 49 \\
\hline To dismiss the government & 80,1 & 74,5 & 68,2 \\
\hline $\begin{array}{l}\text { To make criminal charges against the persons } \\
\text { responsible for assaulting the protesters in } \\
\text { Maidan }\end{array}$ & 57,6 & 50,7 & 63,7 \\
\hline $\begin{array}{l}\text { To dissolve the Verkhovna Rada and call snap } \\
\text { parliamentary elections }\end{array}$ & 55,6 & 51,4 & 59,1 \\
\hline To free Yulia Timoshenko & 37,8 & 36 & 30,4 \\
\hline $\begin{array}{l}\text { To dismiss Viktor Yanukovych and call snap } \\
\text { presidential elections }\end{array}$ & 75,1 & 65,7 & 85,2 \\
\hline $\begin{array}{l}\text { To introduce changes to the Constitution and } \\
\text { restore the constitutional reform of } 2004 \text { that } \\
\text { limits the power of the president }\end{array}$ & 37,9 & 42,8 & 62,5 \\
\hline $\begin{array}{l}\text { To make criminal charges against administrati- } \\
\text { ve officials involved in corruption }\end{array}$ & 49,6 & 42,8 & 62,1 \\
\hline $\begin{array}{l}\text { A general improvement of the standard of } \\
\text { living }\end{array}$ & 46,9 & 42,5 & 41,1 \\
\hline Other & 3,4 & 6,7 & 1,6 \\
\hline Difficult to say & 0 & 0 & 0 \\
\hline
\end{tabular}

Source: Vid Maidanu-taboru do Maidanu-Sichi: shcho zminylosia? (2014); Maidan-mitynh i Maidan-tabir: skhozhe i vidminne (2013).

focus. Throughout the protests, the key postulates remained: to free the arrested demonstrators of Maidan and to penalise those responsible for assaulting the protesters, to dismiss the government, and to dissolve the Verkhovna Rada and call snap parliamentary elections. On the other hand, towards the end of the protests there was a growing support for the postulates to restore the 2004 Constitution and to fight corruption. I. Bekeshkina has rightly noted that in the context of the governmental repression, the level of fear of the government has significantly decreased in society (Karpiak, 2014).

Moreover, according to the first poll, more than a half of the protesters ( $51 \%$ of the respondents) stated that the political opposition, together with social leaders of the Euromaidan, should negotiate with the government, with interna- 
tional organisations as intermediaries. On the other hand, $41.5 \%$ of respondents said that opposition should not start any negotiations with the government (Maidan-2013..., 2013). 45\% of respondents from Maidan-camp agreed that negotiations should take place between the leaders of the opposition and the government, while $47 \%$ were against such negotiations (Maidan-mitynh..., 2013). The third poll was conducted by the Democratic Initiative and KIIS after brutal confrontations between the protesters and officers of the force units. This poll included the members of Maidan-camp, which in the meantime had transformed into Maidan-Sich, according to the experts of sociological agencies. The radicalisation of the protesters is evident in the decrease of the support for negotiations between the political opposition and the government: only $27 \%$ of the respondents supported it, while $63 \%$ were against any talks with the government (Vid Maidanu-taboru..., 2014). Thus, it may be concluded that the parliamentary opposition lost the Euromaidan's mandate to negotiate with the government.

At the same time, it must be stressed that almost all postulates mentioned above that were supported by the demonstrators were in fact articulated and propagated in Maidan by the politicians of the opposition. At the beginning of January 2014, the public opinion was dominated by a conviction that one of the sources of the social and political crisis is the widening of the competences of the head of the state (Khomenko, 2014). The leaders of the opposition were consequently repeating that restoring the Constitution of 2004 which limited the power of the President would help Ukraine get through the political crisis $^{3}$. Once the support for this postulate has notably increased among the protesters at the beginning of February 2014, the opposition entered a bill restoring the 2004 Constitution to the Parliament.

3 A decision to introduce changes to the Constitution of Ukraine of 1996 (on the basis of which a semi-presidential system, with wide competences of the head of the state - the so-called president-parliamentary republic - was introduced) was the foundation of the compromise between the government and the opposition during the Orange Revolution. According to the changes introduced in 2004, the president's influence on the executive power was limited. The main role in appointing the government and the prime minister was played by the parliament, and the so-called parliamentary-presidential republic was introduced, with the remaining semi-presidential form of power. However, in September 2010, the Constitutional Court of Ukraine annulled the amendments introduced in 2004 and reinstated the 1996 Constitution. In this way, President Yanukovych (elected in February 2010) made the extension of his competences possible. 


\section{PREREQUISITES FOR THE NEGOTIATIONS BETWEEN THE OPPOSITION AND THE GOVERNMENT}

For the first two months of the Euromaidan, the government was not particularly interested in entering into negotiations with its leaders. Their only demand was for the protesters to unblock the seats of the governmental institutions in the centre of Kiev (Shurkhalo, 2013).

The opposition also was not unanimously convinced about starting a dialogue with the government. Yulia Timoshenko, the imprisoned leader of "Batkivshchyna", and the leader of UDAR, Vitaly Klitschko, had the most radical attitude to the matter. They stated that in the current situation, any negotiations with the government are unnecessary, and the dismissal of Viktor Yanukovych and snap parliamentary and presidential elections must be demanded (Tymoshenko..., 2013; Klitshko vidmovyvsia..., 2013). On the other hand, the leader of "Svoboda", Oleh Tyahnybok, claimed that negotiations with the government should only be started once the postulates of the opposition are met by the government (Nedilko, 2013). According to the leader of the parliamentary fraction of "Batkivshchyna", Arseniy Yatsenyuk, negotiations between the leaders of the opposition and Viktor Yanukovych would be possible only if supported by the demonstrators of the Euromaidan (Lidery..., 2013).

The first meeting of the government and the opposition took place on December 13,2013, at a round table, under a motto "we will unite the nation", and was rather of a symbolic character. The leaders of the opposition stated that they took part in it "at a request of the non-governmental organisations", supported by the protesters of the Euromaidan („Kruhlyy stil”.., 2013). They presented the following postulates during this meeting: a) to free the arrested demonstrators of Maidan and to dismiss any criminal charges against them; b) to penalise the Minster of Internal Affairs and the officers of force units that were responsible for using force against protesters; c) to dismiss the government; d) to call snap parliamentary and presidential elections (Stern, 2013). Right after the end of the meeting, the opposition told the media that they did not believe in any promises made by the head of the state (Yatsenyuk ne poviryv..., 2013).

The government was truly ready to negotiate with the opposition only in the second half of January 2014. This resulted from, firstly, the escalation of the conflict between the protesters and force units (with casualties), which took place on January 19,2014, after the passing of the so-called 'dictatorship laws' on January 16, 2014, limiting the right to assembly and restricting the freedom of 
speech. Another factor that encouraged the government to start the negotiations was the geographical spread of the protest (Holovko \& Yanishevsky, 2016, p. 568). Due to the fact that a large number of force units were relocated from various areas of the state to Kiev, a decision was made to intensify the protests in oblasts (Koshkina, 2015, p. 189). This allowed the protesters to block and occupy the seats of the main organs of state power and territorial administration, which became an important leverage in the negotiations with the government (Stadnyk, 2014).

\section{NEGOTIATIONS BETWEEN THE GOVERNMENT AND THE OPPOSITION}

Negotiations of the opposition and the government took place behind closed doors. The public learned about the contents of these talks later, from the press release given both by the government and by the parliamentary opposition. Moreover, after each of their meetings with the government, the leaders of opposition joined the protesters at the Independence Square, on the stage of Maidan, to give their reports on negotiations.

The first two meetings (on January 22 and 23, 2014) did not bring any solutions. To the postulates articulated earlier, the leaders of the opposition added the demand to waive the laws passed on January 16, 2014 (Opozyciya zaiavyla..., 2014). On January 22, 2014, to curb the anger of the protesters and to strengthen their position in Maidan, the leaders of the opposition offered an ultimatum for Viktor Yanukovych: within 24 hours, he would have to solve the social and political crisis, stop the bloodshed and punish the responsible. They declared that the protesters will attack force units if these demands are not met. Arseniy Yatsenyuk uttered a phrase that since then has become a meme: "I will not live in disgrace. If I am to get a bullet in the head, I prefer a bullet in the head" (Perehovory..., 2014). On January 23, 2014, the leaders of the opposition managed to direct the attention of the protesters to spreading Maidan to Hrushevsky Street (Savytsky \& Hrabska, 2014) (where the seats of the Verkhovna Rada, the Cabinet of Ministers of Ukraine, a number of ministries and embassies are located). At the same time, the Presidential Administration informed on their website that the negotiations between the government and the opposition had started. On the other hand, the representatives of the government negotiators informed the 
public that the leaders of the opposition had not agreed to condemn violence used by the officers of force unit against the protesters (Lukash..., 2014).

A partial breakthrough took place as a result of the meetings on January 25 and 27,2014. It was a result of the intensification of the protests in various parts of the state (according to the reports on January 24, 2014, the protesters occupied the seats of 8 state territorial administrations, especially in the west and the centre of the country, see: Khronolohiya..., 2014 p. 959). These negotiations resulted in: waiving the laws passed on January 16, 2014 during a special session of the parliament on January 28, 2014; dismissal of the government led by M. Azarov; the next day, passing a law on desisting from criminal and administrative prosecution of the arrested protesters of the Euromaidan (Zakon Ukrainy No. 737-VII). To ensure the passage of this law, the protesters agreed to the condition posed by the government and unblocked the traffic in the streets and left the governmental and territorial administrative buildings in the capital and in oblasts. However, the government did not fulfil all of their promises. Out of 2,000 criminal and administrative cases, only 108 were dismissed (Pshonka..., 2014), which indicates that the harassment of the demonstrators by the government continued. Moreover, the opposition informed the protesters that the President agreed to commence works on restoring the 2004 Constitution (Savytsky, 2014). Yet, the government negotiators refuted this information, claiming that there had been only a decision made to establish a working group made of representatives of the government and the opposition that would be involved in preparing changes to the Constitution (which would later be implemented by the government or by way of national referendum) (Amnistiya..., 2014).

Therefore, during a Sunday rally in Kiev on February 16, 2014, the leaders of the opposition called the protesters to come to the seat of the Parliament - a peaceful advance on the Verkhovna Rada - in order to demand that the deputies pass a normative act that would restore the Constitution of 2004 (Pavlyk, 2014). During the march of February 18, 2014, a brutal confrontation between the protests and the officers of force units and another attempt to disperse the tent city on the Independence Square took place. These events resulted in casualties on both sides. The confrontation lasted till February 20, 2014 (on that day, snipers from special units shot the demonstrators of Maidan). Due to the escalation of the conflict in Kiev, the protesters again started to attack and occupy the governmental seats in oblasts (Khronolohiya..., 2014, p. 970).

At the same time, on February 18, 2014, the negotiations between the government and the opposition were renewed. During their meetings, both sides 
accused each other for disrespecting their earlier arrangements. Viktor Yanukovych demanded from the leaders of the opposition to stop the protests and dissolve Maidan, and threatened that they will be held accountable (Khronolohiya..., 2014, pp. 969-970). On the other hand, the political opposition replied that they cannot dissolve Maidan, as they were not the ones who called it (Yanukovych maie ..., 2014). They also stressed that it is up to Viktor Yanukovych to stop the escalation of the conflict, solve the political crisis, lead to a complete truce, and stop using force against the protesters. The leaders of the opposition stated that a fitting compromise in this situation would be to restore the 2004 Constitution (Yanukovych maie ..., 2014).

Making an agreement between the President and the leaders of the opposition became possible on February 21, 2014 thanks to the mediation of the EU's diplomatic mission and participation of foreign affair ministers from Poland, Germany and France. According to the agreement, the Verkhovna Rada was to pass a law reinstating the Constitution of 2004. In turn, by signing the agreement, President Yanukovych obliged to sign this law. Next, on the basis of the new text of the Constitution, a new government was to be appointed. Until September 2014, a constitutional reform was to be conducted, and snap presidential elections were to take place before December 2014. The government also committed itself to desist from persecuting the protesters, while the opposition - to stop using violence against the officers of the force units (Uhoda..., 2014). The Euromaidan demonstrators had an ambivalent attitude to this agreement. Some of them (especially those affiliated with the Civil Sector, the Democratic Alliance and the Right Sector) showed a negative response to the compromise between the government and the opposition, and claimed that Yanukovych's dismissal should be immediate. Therefore the protesters made an ultimatum to President Yanukovych. However, V. Yanukovych did not fulfil the obligations of the agreement, in particular he refused to sign the law that restored the 2004 Constitution (Zaiava MSZ..., 2014). He escaped Ukraine and moved to the Russian Federation, which paralysed the whole state that operated in the semi-presidential system of governance.

On February 21, 2014, the Parliament passed the law restoring the Constitution of 2004 (Zakon Ukrainy No. 742-VII). This law became implemented with a parliamentary resolution. That day the Parliament passed also the Law on the Resignation of the President of Ukraine from his Constitutional Competences and Calling Early Presidential Elections in Ukraine (Postanova Verkhovnoi Rady Ukrainy No. 757-VII). On the basis of the 2004 Constitution, the Parliament 
appointed the head of the Verkhovna Rada, who then became appointed as acting President; a new government and heads of other institutions that were key to the functioning of the state were also established. The Verkhovna Rada made a number of decisions that were dictated by the political goal to resolve the social and political crisis, although they were controversial from a legal point of view.

\section{CONCLUSIONS}

It may be concluded that the main goal of the parliamentary opposition in their negotiations with the government was to restore the 2004 Constitution that limited the presidential competences in executive power and extended the parliamentary competences in this respect. Therefore, the hypothesis that the leaders of the opposition used the Euromaidan as a means to limit the presidential power of V. Yanukovych has been fully confirmed. One of the key factors that made the President sign the agreement with the opposition was the collapse of power on February 20-21, 2014. Yanukovych attempted to retain power, but losing propresidential majority in the Parliament thwarted these efforts (Matsiyevsky, 2016, p. 443). As a result of his actions during the protests, Yanukovych lost some of his support and, as it has been rightly noted by $\mathrm{H}$. Hale, created an impression that he cannot keep his power (Hale, 2015, p. 237). His escape from the county allowed the opposition to overtake state power on the basis of the 2004 Constitution.

\section{ReFERENCES:}

Amnistiya, posty w Kabminie, skandalnyie zakony: chto priedlozhil oppozicii Yanukovich (2014, January 25). Retrieved from: https://glavred.info/politics/269409-amnistiyaposty-v-kabmine-skandalnye-zakony-chto-predlozhil-oppozicii-yanukovich.html. Aslund, A. (2015). Ukraine: What Went Wrong and How to Fix It. Washington: Peterson Institute for International Economics.

Bekeshkina, I. (2014). Maidan: Khto, chomu i navishcho? Socialni vymiry suspilstva, 6(17), 304-313.

Hale, H. (2015). Patronal Politics: Eurasian Regime Dynamics in Comparative Perspective. New York: Cambridge University Press.

Holovko, V., \& Yanishevsky, S. (2016). Revoluciya hidnosti. In: S. Kulchytsky, O. Maiboroda, W. Smoliy, L. Yakubova, \& S. Yanishevsky (Eds.).. 25 rokiv nezalezhnosti: narysy istoriyi tvorennia naciyi ta derzhavy (pp. 547-598). Kyiv: Nika-Centr. 
Karpiak, O. (2014, February 4). Iryna Bekeshkina: chas hraie na obyednannia Ukrainy. Retrieved from: https://www.bbc.com/ukrainian/politics/2014/02/140204_bekeshkina_maidan_interview_ko.

Khomenko, S. (2014, January 30). Usi sposoby povernutysia do Konstytuciyi-2004. Retrieved from: https://www.bbc.com/ukrainian/politics/2014/01/140130_constitution_2004_sx.

Khronolohiya ukraiinskoi Revoluciyi hidnosti (21 lystotada 2013 roku - 27 lutoho 2014 roku) (2014). In: O. Zadorozhniy (Ed.). Ukrainska revoluciya hidnosti, ahresija $R F$ i mizhnarodne prawo (pp. 944-981). Kyiv: K.I.S.

Klitshko vidmovyvsia shukaty $z$ Yanukovychem kompromis (2013, December 11). Retrieved from: https://dt.ua/POLITICS/klichko-vidmovivsya-shukati-z-yanukovichem-kompromis-133699_.html.

Klitshko: Yanukovych khoche, shchob Maidan pishov dodomu (2014, February 19). Retrieved June 23, 2020 from: https://www.pravda.com.ua/news/2014/02 /19/7014626/.

Koshkina, S. (2015). Maidan. Nerasskazannaia istoriia. Kyiv: Brait Star Pablishyng. „Kruhlyy stil” perervavsia do vivtorka (2013, December 13). Retrieved from: https:// www.bbc.com/ukrainian/politics/2013/12/131213_round_table_kyiv_hk.

Lidery opozyciyi zaiavyly, shcho ne pidut' na perehovory $z$ vladoiu bez „mandatu Yevromaidanu” (2013, December 11). Retrieved from: https://www.unian.ua/ politics/862466-lideri-opozitsiji-zayavili-scho-ne-pidut-na-peregovori-z-vladoyubez-mandatu-evromaydanu.html.

Lukash: Lidery opozyciyi vdruhe vidmovylysia zasudyty ekstremists'ki diyi. Perehovory bude prodovzheno (2014, January 23). Retrieved from: https://www.unian.ua/ politics/875873-lukash-lideri-opozitsiji-vdruge-vidmovilisya-zasuditi-ekstremistski-diji-peregovori-bude-prodovjeno.html.

Maidan-2013: Khto stoit', chomu i za shcho? (2013, December 10). Retrieved from: http://kiis.com.ua/?lang=ukr\&cat=reports\&id=216\&page $=1 \& y=2013 \& \mathrm{~m}=12$.

Maidan-mitynh i Maidan-tabir: schozhe i vidminne (2013, December 26). Retrieved from: https://dif.org.ua/article/maydan-miting-i-maydan-tabir-skhozhe-ividminne.

Matsiyevsky, Y. (2016). U pastci hibrydnosti: zygzagy transformacii politychnoho rezhymu v Ukraini (1991-2014). Chernivci: Knygy - XXI.

Nedilko, N. (2013, December 11). Yanukovych klyche na kruhlyy stil. Opozyciya yomu ne viryt'. Retrieved from: https://www.dw.com/uk/янукович-кличе-на-круглийстіл-опозиція-йому-не-вірить/а-17288762.

Opozyciya zaiavyla pro bezrezultatni perehovory $z$ Yanukovychem i daie yomu dobu dlya vyrishennia konfliktu (2014, January 22). Retrieved from: https://ukranews.com/ua/ news/228229-opozyciya-zayavyla-pro-bezrezultatni-peregovory-z-yanukovychemi-daye-yomu-dobu-dlya-vyrishennya-konfliktu.

Panchyshyn, O. (2014, January 5). Maidan maie buty aktyvnyy do vyboriv prezydenta - Yatsenyuk. Retrieved from: https://zaxid.net/maydan_maye_buti_aktivniy_do_ viboriv_prezidenta_yatsenyuk_n1300335. 
Pavlyk, A. (2014, February 16). Maidan yde u „myrnyy nastup”. I yakshcho treba, znovu zakhopyt' KMDA - opozyciya. Retrieved from: https://www.radiosvoboda. org/a/25265966.html.

Perehovory: shcho hotovyj obhovoriuvaty Yanukovych (2014, January 23). Retrieved from: https://ua-news.liga.net/politics/articles/peregovori_shcho_gotoviy_obgovoryuvati_yanukovich.

Postanova Verkhovnoi Rady Ukrainy No. 757-VII. Pro samousunennia Prezydenta Ukrainy vid vykonannia konstytutsiynykh povnovazhen' ta pryznachennia pozacherhowych vyboriv Prezydenta Ukrainy (2014). Vidomosti Verkhovnoi Rady, 11, par. 158.

Pshonka: Zakon pro amnistiyu nabude czynnosti 17 lutoho. Ludei zvilniat' protiahom misiatsia (2014, February 16). Retrieved from: https://www.pravda.com.ua/ news/2014/02/16/7014035/.

Savytsky, O. (2014, January 25). Opozyciyni lidery dopovily Maidanu pro perehovory $z$ Yanukovychem. Retrieved from: https://www.dw.com/uk/опозиційні-лідеридоповіли-майдану-про-переговори-з-януковичем/а-17387372.

Savytsky, O., \& Hrabska, A. (2014, January 24). Pisla perehovoriv: na Hrushevskoho znovu hrymyt',"muzyka revoluciyi". Retrieved from: https://www.dw.com/uk/післяпереговорів-на-грушевського-знову-гримить-музика-революції/а-17384080.

Shurkhalo, D. (2013, December 5). Na zavadi perehovoram vlady ta opozyciyi stoiat' represiyi ta blokuvannia. Retrieved from: https://www.radiosvoboda. org/a/25190488.html.

Stadnyk, H. (2014, February 17). Eksperty: zakhoplennia ODA - diya, shcho sebe vypravdala. Retrieved February 23, 2020 from: https://www.dw.com/uk/експертизахоплення-ода-дія-що-себе-виправдала/а-17438105.

Stern, D. (2013, December 14). Yatseniuk: „My zumily ne dopustyty vojennoho perevorotu". Retrieved from: https://www.bbc.com/ukrainian/politics/2013/12/131214_ yatsenyuk_interview_stern_or.

Tymoshenko zaklykala "yevromaidanivciv" ne vesty perehovoriv $z$ Yanukovychem (2013, December 11). Retrieved from: https://ukranews.com/ua/news/223138tymoshenko-zaklykala-yevromaydanivciv-ne-vesty-peregovoriv-z-yanukovychem.

Uhoda pro vrehuluvannia kryzy v Ukraini (2014, February 21). Retrieved from: https:// www.pravda.com.ua/articles/2014/02/21/7015533/.

Vid Maidanu-taboru do Maidanu-Sichi: shcho zminylosia? (2014, February 6). Retrieved from: https://dif.org.ua/article/vid-maydanu-taboru-do-maydanu-sichi-shchozminilosya.

Wilson, A. (2014). Ukraine Crisis: What It Means for the West. New Haven-London: Yale University Press.

Yanukovych maie vidvesty sylovykiv vid Maidanu - zaiava opozyciyi (2014, February 19). Retrieved from: https://zik.ua/news/2014/02/19/yanukovych_maie_vidvesty_sylovykiv_z_maydanu_zayava_opozytsii_462318.

Yatsenyuk ne poviryv u moratoriy Yanukovycha (2013, December 13). Retrieved from: https:/www.pravda.com.ua/news/2013/12/13/7006761/. 
Zaiava MZS Ukrainy shchodo vykonannia Uhody pro vrehuluvannia kryzy vid 21 lutoho (2014, February 28). Retrieved from: https://www.kmu.gov.ua/ua/news/247060719/. Zakon Ukrainy No. 737-VII. Pro usunennia nehatyvnych naslidkiv ta nedopushchennia peresliduvannia ta pokarannia osib z pryvodu podiy, yaki maly mistse pid chas provedennia myrnykh zibran. (2014). Vidomosti Verkhovnoi Rady, 12, par. 185.

Zakon Ukrainy No. 742-VII. Pro vidnovlennia diyi okremykh polozhen' Konstytutsiyi Ukrainy. (2014). Vidomosti Verkhovnoi Rady, 11, par. 143. 